\title{
A novel combination treatment for breast cancer cells involving BAPTA-AM and proteasome inhibitor bortezomib
}

\author{
AZMI YERLIKAYA ${ }^{1}$, ELIF ERDOĞAN $^{2}$, EMRAH OKUR $^{2}$, ŞERIFE YERLIKAYA ${ }^{3}$ and BIRCAN SAVRAN $^{4}$ \\ ${ }^{1}$ Department of Medical Biology, Faculty of Medicine; Departments of ${ }^{2}$ Biology and ${ }^{3}$ Biochemistry, \\ Faculty of Arts and Sciences; ${ }^{4}$ Department of Pediatrics, Faculty of Medicine, Dumlupınar University, Kütahya 43100, Turkey
}

Received June 24, 2015; Accepted April 29, 2016

DOI: 10.3892/ol.2016.4597

\begin{abstract}
Glucose-regulated protein $78 \mathrm{kDa} /$ binding immunoglobulin protein (GRP78/BIP) is a well-known endoplasmic reticulum (ER) chaperone protein regulating ER stress by facilitating protein folding, assembly and $\mathrm{Ca}^{2+}$ binding. GRP78 is also a member of the heat shock protein 70 gene family and induces tumor cell survival and resistance to chemotherapeutics. Bortezomib is a highly specific $26 \mathrm{~S}$ proteasome inhibitor that has been approved as treatment for patients with multiple myeloma. The present study first examined the dose- and time-dependent effects of bortezomib on GRP78 expression levels in the highly metastatic mouse breast cancer 4T1 cell line using western blot analysis. The analysis results revealed that GRP78 levels were significantly increased by bortezomib at a dose as low as $10 \mathrm{nM}$. Time-dependent experiments indicated that the accumulation of GRP78 was initiated after a $24 \mathrm{~h}$ incubation period following the addition of $10 \mathrm{nM}$ bortezomib. Subsequently, the present study determined the half maximal inhibitory concentration of intracellular calcium chelator BAPTA-AM $(13.6 \mu \mathrm{M})$ on $4 \mathrm{~T} 1$ cells. The combination effect of BAPTA-AM and bortezomib on the 4T1 cells was investigated using 3-(4,5-dimethylthiazol-2-yl)-2,5-diphenyltetrazolium bromide and WST-1 assays and an iCELLigence system. The results revealed that the combination of $10 \mathrm{nM}$ bortezomib $+5 \mu \mathrm{M}$ BAPTA-AM is more cytotoxic compared with monotherapies, including $10 \mathrm{nM}$ bortezomib, $1 \mu \mathrm{MBAPTA}-\mathrm{AM}$ and $5 \mu \mathrm{M}$ BAPTA-AM. In addition, the present results revealed that bortezomib + BAPTA-AM combination causes cell death through the induction of apoptosis. The present results also revealed that bortezomib + BAPTA-AM combination-induced apoptosis is associated with a clear increase in the phosphorylation of stress-activated protein kinase/Jun amino-terminal kinase SAPK/JNK. Overall, the present results suggest that bortezomib and BAPTA-AM combination therapy may be a novel therapeutic strategy for breast cancer treatment.
\end{abstract}

Correspondence to: Dr Azmi Yerlikaya, Department of Medical Biology, Faculty of Medicine, Dumlupınar University, Evliya Çelebi Yerleşkesi, Tavşanlı Yolu 10. Km, Kütahya 43100, Turkey

E-mail: azmiyerlikaya@yahoo.com

Key words: bortezomib, BAPTA-AM, cancer, GRP78, proteasome

\section{Introduction}

Glucose-regulated protein $78 \mathrm{kDa} /$ binding immunoglobulin protein (GRP78/BIP) is an endoplasmic reticulum (ER) chaperone protein and a member of the heat shock protein (Hsp) 70 family. GRP78 has critical roles in protein homeostasis and the unfolded protein response. It has been identified in numerous organisms from yeast to humans (1-4). The expression of GRP78 clearly increases during ER stress, and therefore is used as an ER stress marker (4). In addition, GRP78 is involved in the integrity and the regulation of the ER, and it prevents the aggregation of misfolded proteins, including apoB100, by targeting them to the degradation by the $26 \mathrm{~S}$ proteasome (5). When ER stress occurs, GRP78 is separated from inositol-requiring enzyme 1, protein kinase RNA-like endoplasmic reticulum kinase and/or activating transcription factor 6, thus enabling them to be activated, which leads to the unfolded protein response, cell survival or apoptosis (4).

Studies have revealed that GRP78 is overexpressed in a wide range of tumors and therefore may be responsible for the resistance to hormonal therapies as well as chemotherapeutics. Zhang et al (6) previously demonstrated that breast and prostate cancer cells resistant to hormonal therapy actively promote GRP78 to the cell surface. In addition, that study revealed that soluble GRP78 forms a complex with phosphoinositide 3-kinase (PI3K), leading to PI3K activation, which is known be activated in various cancer cells resulting in proliferation and therapeutic resistance (6). In addition, GRP78 forms were identified as mediating resistance to ionizing radiation in a stem cell-like subpopulation within the human breast cancer MCF-7 cell line (7). Furthermore, when GRP78 is suppressed by lentiviral vectors expressing small interfering (si) RNA, human breast cancer cells become sensitized to etoposide-mediated cell death (8). Dong et al (8) demonstrated that treatment with combretastatin A4P, a vascular targeting agent, or contortrostatin, an antiangiogenic agent, promoted transcriptional activation of the GRP78 promoter and increased GRP78 protein in MDA-MB-435 xenografts tumor cells. Additionally, the level of GRP78 expression in primary tumors from resected gastric cancer and metastatic lymph nodes was inversely associated with patient survival (9). Zhang et al (9) demonstrated that knocking down GRP78 expression inhibits tumor cell invasion, growth and metastasis in a xenograft nude mouse model; therefore, leading to the conclusion that 
a dysregulated expression of GRP78 may contribute to the development and progression of gastric cancer.

Wang et al (10) reported that GRP78 expression appears to be critical to the responsiveness of proteasomal inhibition in various thyroid cancer cell lines; it was demonstrated that insensitive thyroid cancer cell lines are sensitized to the proteasome inhibition by suppression of GRP78. The 26S proteasome inhibitor bortezomib, also known as Velcade or PS-341, interferes with ER responses and improves survival of patients with aggressive hematologic malignant tumors (11). siRNA silencing of GRP78 renders diffuse large B-cell lymphoma (DLBCL) cell lines sensitive to bortezomib (11). Chen et al (12) demonstrated that exposure of 91 rat brain cells to low concentrations of thapsigargin (TG), a sarcoendoplasmic $\mathrm{Ca}^{2+}$-ATPase inhibitor, leads to immediate suppression of general protein synthesis and enhanced induction of GRP78. Those authors also revealed that TG-induced GRP78 expression may be suppressed by cytosolic free calcium $\left(\mathrm{Ca}^{2+}{ }_{\mathrm{c}}\right)$ chelator dibromo-1,2-bis (aminophenoxy) ethane $\mathrm{N}, \mathrm{N}, \mathrm{N}^{\prime}$, $\mathrm{N}^{\prime}$-tetraacetic acid (BAPTA), which enters cells as an ester derivative BAPTA-acetoxymethyl ester (BAPTA-AM), and the induction of GRP78 expression was completely inhibited in the presence of $20 \mu \mathrm{M}$ BAPTA-AM (12). Mozos et al (11) demonstrated that reducing GRP78 expression by treating bortezomib-resistant DLBCL cell lines with prednisone overcomes bortezomib resistance.

The current study examined the expression of GRP78 in response to bortezomib-treatment in the highly metastatic mouse breast cancer 4T1 cell line. The present results revealed that GRP78 is significantly induced in a dose- and time-dependent manner following low doses of bortezomib-treatment. In addition, the results demonstrated that combination treatment with bortezomib and the intracellular calcium chelator BAPTA-AM may be a novel treatment strategy for breast cancer.

\section{Materials and methods}

Materials. RPMI-1640 media, fetal bovine serum (FBS), penicillin/streptomycin, 3-(4,5-dimethylthylthiazol-2-yl)-2,5-diphenyl-tetrazolium bromide (MTT), leupeptin and BAPTA-AM were obtained from Sigma-Aldrich (St. Louis, MO, USA). Rabbit polyclonal anti-GRP78 and anti-ubiquitin antibodies were obtained from Santa Cruz Biotechnology, Inc. (Dallas, TX. USA), and rabbit polyclonal anti- $\beta$-actin antibody was obtained from Abcam (Cambridge, MA, USA). Cell Proliferation Reagent WST-1 was obtained from Roche Diagnostics GmbH (Mannheim, Germany). Bortezomib was generously provided by Dr Engin Ulukaya (Uludağ University, Bursa, Turkey). All other reagents were purchased from Sigma-Aldrich unless otherwise specified.

Cell culture. Mouse breast cancer 4T1 cell line (obtained from Dr Nuray Erin, Akdeniz University, Antalya, Turkey) was cultured in RPMI-1640 (plus $4.5 \mathrm{~g} / 1$ glucose, $10 \mathrm{mM}$ HEPES, $1 \mathrm{mM}$ sodium pyruvate, $0.15 \%$ sodium bicarbonate, $100 \mu \mathrm{g} / \mathrm{ml}$ streptomycin and $100 \mathrm{U} / \mathrm{ml}$ penicillin) containing $10 \%$ FBS. Cell cultures were maintained at $37^{\circ} \mathrm{C}$ in a $5 \%$ $\mathrm{CO}_{2}$ humidified incubator in $25 \mathrm{~cm}^{2}$ Corning flasks (Corning Incorporated, Corning, NY, USA). The cells were subcultured at $\sim 70 \%$ confluency.
Western blot analysis. 4T1 cells $(100,000$ per $35 \times 10 \mathrm{~mm}$ petri dishes) were treated with dimethyl sulfoxide (DMSO; control), $10 \mu \mathrm{M}$ leupeptin or various concentrations of bortezomib (10-200 nM) for $24 \mathrm{~h}$. For time-dependent experiments, the cells were treated with $10 \mathrm{nM}$ bortezomib for 12, 24 and $48 \mathrm{~h}$. After treatment, the cells were lyzed with radioimmunoprecipitation assay lysis buffer containing protease inhibitor cocktail. A total of 25 or $40 \mu \mathrm{g}$ protein from each sample was separated by $12 \%$ sodium dodecyl sulfate (SDS) polyacrylamide gel electrophoresis. Subsequently, the proteins were transferred to polyvinylidene difluoride membranes at $70 \mathrm{~V}$ for $2 \mathrm{~h}$. Subsequently, the membranes were blocked with $5 \%$ non-fat dried milk in Tris-buffered saline with Tween 20 (TBS-T). The membranes were then incubated with GRP78 antibody (1:500; catalog no., sc-13968), ubiquitin antibody (1:200; catalog no., sc-9133) or $\beta$-actin antibody (1:500; catalog no., ab8227) in TBS-T for $1 \mathrm{~h}$. The membranes were incubated with donkey anti-rabbit horseradish peroxidase (HRP)-conjugated secondary antibody (1:5,000; catalog no., NIF824; GE Healthcare, Chalfont, UK) in TBS-T for $1 \mathrm{~h}$. Finally, the membranes were incubated with Amersham ECL Western Blotting Detection Reagent (GE Healthcare) and exposed to BioMax ${ }^{\circledR}$ X-ray films (Kodak, Rochester, NY, USA) in a dark room.

MTT-based cytotoxicity assay. In total, 100,000 cells were seeded in $35 \times 10 \mathrm{~mm}$ Corning plates. In the logarithmic phase of growth, the cells were treated with various doses of BAPTA-AM and bortezomib $(0.5 \mu \mathrm{M}$ BAPTA-AM, $5 \mu \mathrm{M}$ BAPTA-AM, $1 \mathrm{nM}$ bortezomib, $10 \mathrm{nM}$ bortezomib, $0.5 \mu \mathrm{M}$ BAPTA-AM + $1 \mathrm{nM}$ bortezomib, $0.5 \mu \mathrm{M}$ BAPTA-AM + $10 \mathrm{nM}$ bortezomib, $5 \mu \mathrm{M}$ BAPTA-AM $+1 \mathrm{nM}$ bortezomib and $5 \mu \mathrm{M}$ BAPTA-AM + $10 \mathrm{nM}$ bortezomib) for $24 \mathrm{~h}$. Following inhibitor exposure, the cells were treated for $24 \mathrm{~h}$ with RPMI-1640 media containing $0.5 \% \mathrm{FBS}+0.5 \mathrm{mg} / \mathrm{ml} \mathrm{MTT}$ at $37^{\circ} \mathrm{C}$ with $5 \% \mathrm{CO}_{2}$. Subsequently, the cells were incubated with $3 \%$ SDS $(200 \mu \mathrm{l})+40 \mathrm{mM} \mathrm{HCl} /$ isopropanol $(1 \mathrm{ml})$ for $15 \mathrm{~min}$ in order to dissolve the MTT-formazan crystals. The absorbance of each sample was recorded at $570 \mathrm{~nm}$ (13-15). Cell survival was determined by analyzing the data with GraphPad Prism 3.03 software (GraphPad Software, Inc., La Jolla, CA, USA).

Half maximal inhibitory concentration $\left(I C_{50}\right)$ determination. MTT assay was performed as previously described to determine the $\mathrm{IC}_{50}$ of BAPTA-AM on $4 \mathrm{~T} 1$ cells. The cells were treated with 100 and $500 \mathrm{nM}$ and 1, 10, 50 and $100 \mu \mathrm{M}$ BAPTA-AM. The $\mathrm{IC}_{50}$ value of BAPTA-AM was obtained by fitting the data with a GraphPad Prism 3.03 program to a sigmoidal dose-response curve.

WST-1-based cytotoxicity assay. In total, 1,000 cells were seeded in each well of a 96-well plate. In the logarithmic phase of growth, the cells were treated with various doses of BAPTA-AM and bortezomib (5 $\mu \mathrm{M}$ BAPTA-AM, $1 \mathrm{nM}$ bortezomib, $10 \mathrm{nM}$ bortezomib, $5 \mu \mathrm{M}$ BAPTA-AM $+1 \mathrm{nM}$ bortezomib and $5 \mu \mathrm{M}$ BAPTA-AM $+10 \mathrm{nM}$ bortezomib) for $24 \mathrm{~h}$. Following inhibitor exposure, the cells were treated for $1 \mathrm{~h}$ with RPMI-1640 media containing $0.5 \% \mathrm{FBS}+10 \mathrm{mg} / \mathrm{ml}$ WST- 1 at $37^{\circ} \mathrm{C}$ with $5 \% \mathrm{CO}_{2}$. Subsequently, the absorbance of the wells was recorded by a microplate reader at $450 \mathrm{~nm}$ with a reference wavelength at $630 \mathrm{~nm}$. 
iCELLigence system. In total, 12,500 cells were seeded onto an E-Plate L8 within an iCELLigence system (ACEA Biosciences, San Diego, CA, USA), which has integrated microelectrode sensors in the bottom of the wells, and were incubated at $37^{\circ} \mathrm{C}$ with $5 \% \mathrm{CO}_{2}$ for $96 \mathrm{~h}$. In an iCELLigence system, as the cells proliferate they adhere to the micro-electrodes, and alterations in electrical impedance reflect the biological status of the cells; therefore, the system allows monitoring of time-dependent effects on a cell culture. Cell status is expressed as cell index (CI). In total $24 \mathrm{~h}$ later, in the logarithmic phase of the growth, the cells were treated with $10 \mathrm{nM}$ bortezomib, $1 \mu \mathrm{M}$ BAPTA-AM, $5 \mu \mathrm{M}$ BAPTA-AM, $1 \mu \mathrm{M}$ BAPTA-AM + $10 \mathrm{nM}$ bortezomib or $5 \mu \mathrm{M}$ BAPTA-AM $+10 \mathrm{nM}$ bortezomib. Following a $1 \mathrm{~h}$ treatment time, CI measurements were taken.

Apoptotic DNA isolation. In total, 200,000 4T1 cells were seeded in $60 \times 15 \mathrm{~mm}$ sterile petri dishes and treated with $10 \mathrm{nM}$ bortezomib, $1 \mu \mathrm{M}$ BAPTA-AM, $5 \mu \mathrm{M}$ BAPTA-AM, $10 \mathrm{nM}$ bortezomib $+1 \mu \mathrm{M}$ BAPTA-AM or $10 \mathrm{nM}$ bortezomib $+5 \mu \mathrm{M}$ BAPTA-AM at the logarithmic phase of growth for $24 \mathrm{~h}$. Control cells were treated with dimethyl sulfoxide (vehicle for BAPTA-AM). Following treatment, the cells were washed with $1 \mathrm{ml}$ phosphate-buffered saline (PBS) and resuspended in $200 \mu \mathrm{l}$ PBS. An Apoptotic DNA-Ladder kit (Roche Diagnostics $\mathrm{GmbH}$ ) was used to isolate DNA, according to the manufacturer's protocol. Equal amounts of DNA $(1 \mu \mathrm{g})$ from each sample were separated by $1.5 \%$ agarose gel electrophoresis at $80 \mathrm{~V}$ for $2 \mathrm{~h}$. DNA was visualized by ethidium bromide staining under UV light.

Annexin $V$ and dead cell analyses. In total, 200,000 4T1 cells were seeded in $60 \times 15 \mathrm{~mm}$ sterile petri dishes, and cells in the logarithmic phase of growth were treated for $24 \mathrm{~h}$ with $10 \mathrm{nM}$ bortezomib, $1 \mu \mathrm{M}$ BAPTA-AM, $5 \mu \mathrm{M}$ BAPTA-AM, $10 \mathrm{nM}$ bortezomib $+1 \mu \mathrm{M}$ BAPTA-AM or $10 \mathrm{nM}$ bortezomib $+5 \mu \mathrm{M}$ BAPTA-AM. Following treatment, a $100 \mu \mathrm{l}$ cell sample was prepared using 40,000 cells and 1\% FBS. In total, $100 \mu 1$ Muse ${ }^{\circledR}$ Annexin V and Dead Cell Reagent (EMD Millipore, Billerica, MA, USA) was added to each sample. The cell samples were mixed thoroughly by pipetting up and down or vortexing at a medium speed for 3-5 sec and were left to stain for $20 \mathrm{~min}$ at room temperature in the dark. Following staining, the apoptotic effects of the inhibitors were analyzed by a Muse ${ }^{\circledR}$ Cell Analyzer (EMD Millipore).

Analysis of intracellular signaling molecules. PathScan ${ }^{\circledR}$ Intracellular Signaling Array kit (Cell Signaling Technology, Inc., Danvers, MA, USA) was used, according to the manufacturer's protocol, for the detection of phosphorylation or cleavage of the following 18 well-characterized signaling molecules: Extracellular signal-regulated kinases $1 / 2$ (Thr202/Tyr204); Signal transducer and activator of transcription (Stat) 1 (Tyr701); Stat3 (Tyr705); Akt (Thr308); Akt (Ser473); AMP-activated protein kinase $\alpha$ (Thr172); S6 ribosomal protein (Ser235/236); mechanistic target of rapamycin (Ser2,448); Hsp27 (Ser78); Bcl-2-associated death promoter (Ser112); p70 S6 kinase (Thr389); proline-rich Akt substrate of $40 \mathrm{kDa}$ (Thr246); p53 (Ser15); p38 (Thr180/Tyr182); stress-activated protein and Jun amino-terminal kinases (SAPK/JNK; Thr183/Tyr185); poly (ADP-ribose) polymerase
(Asp214); caspase-3 (Asp175); and glycogen synthase kinase-3 $\beta$ (Ser9).

Briefly, 200,000 cells were seeded in $60 \times 15 \mathrm{~mm}$ sterile petri dishes and treated with $10 \mathrm{nM}$ bortezomib, $100 \mathrm{nM}$ bortezomib, $1 \mu \mathrm{M}$ BAPTA-AM, $5 \mu \mathrm{M}$ BAPTA-AM, $10 \mathrm{nM}$ bortezomib $+1 \mu \mathrm{M}$ BAPTA-AM, $10 \mathrm{nM}$ bortezomib $+5 \mu \mathrm{M}$ BAPTA-AM, $100 \mathrm{nM}$ bortezomib $+1 \mu \mathrm{M}$ BAPTA-AM or $100 \mathrm{nM}$ bortezomib $+5 \mu \mathrm{M}$ BAPTA-AM at the logarithmic phase of the growth for $24 \mathrm{~h}$. Following treatment, the medium was removed and the cells were washed with ice-cold 1X PBS. Subsequently, $0.3 \mathrm{ml}$ ice-cold cell lysis buffer was added to each plate and incubated on ice for $5 \mathrm{~min}$. The lysate was centrifuged at $10,000 \mathrm{x} \mathrm{g}$ for $10 \mathrm{~min}$ at $4^{\circ} \mathrm{C}$. The protein concentration was determined using the Bio-Rad Protein Assay (Bio-Rad Laboratories, Inc., Hercules, CA, USA) with bovine serum albumin as a standard. Briefly, the glass slide array containing the antibodies for the proteins to be analyzed was affixed to a multi-well plate. Subsequently, $100 \mu \mathrm{l}$ array blocking buffer was added to each well, the wells were covered with sealing tape and incubated for $15 \mathrm{~min}$ at room temperature on an orbital shaker. Following blocking, $75 \mu \mathrm{l}$ diluted lysate ( $45 \mu \mathrm{g}$ protein) was added to each well and was incubated for $2 \mathrm{~h}$ at room temperature on an orbital shaker. Following washing, $75 \mu \mathrm{l}$ 1X detection antibody cocktail was added to each well and incubated for $1 \mathrm{~h}$. Subsequently, $75 \mu$ 1 1X HRP-linked streptavidin was added to each well for $30 \mathrm{~min}$ at room temperature. Following washing, the plate was incubated with Lumi-GLO ${ }^{\circledR} /$ peroxide Reagent (Cell Signalling Technology, Inc.) for $2 \mathrm{~min}$ and exposed to Kodak BioMax X-ray films in a dark room.

Statistical analysis. Results were analyzed with GraphPad Prism 3.03 software. Statistical differences between the samples were evaluated using one-way analysis of variance and Bonferroni or Newman-Keuls post-hoc comparisons. $\mathrm{P}<0.05$ was considered to indicate a statistically significant difference.

\section{Results}

Effect of bortezomib on GRP78 expression and proteasome inhibition. The clinical efficacy of proteasome inhibitor bortezomib is hampered by drug-resistant cell phenotypes (16). Although there may be a number of resistance mechanisms to bortezomib, one primary mechanism is the constitutively high expression of Hsp27 (17). Initially, the present study investigated the effect of bortezomib on GRP78 expression in a dose- and time-dependent manner in metastatic mouse breast cancer 4T1 cells. The cells were treated with various doses of bortezomib (10, 50, 100 and $200 \mathrm{nM})$ and $10 \mu \mathrm{M}$ leupeptin, an inhibitor of lysosomal proteases for $24 \mathrm{~h}$, and GRP78 expression was determined by western blot analysis. As shown in Fig. 1A, bortezomib treatment increased the expression of GRP78 in a threshold-dependent manner. The highest increase in GRP78 expression was observed in response to $10 \mathrm{nM}$ bortezomib treatment. With higher doses of bortezomib, there was a slight decrease in GRP78 expression compared with $10 \mathrm{nM}$ bortezomib. In contrast to expectations, leupeptin also enhanced the expression of GRP78. These results suggest that, in addition to the proteasome, the lysosome plays a role in the regulation of GRP78 expression. To determine whether the proteasome was inhibited with bortezomib treatment, the accumulation 

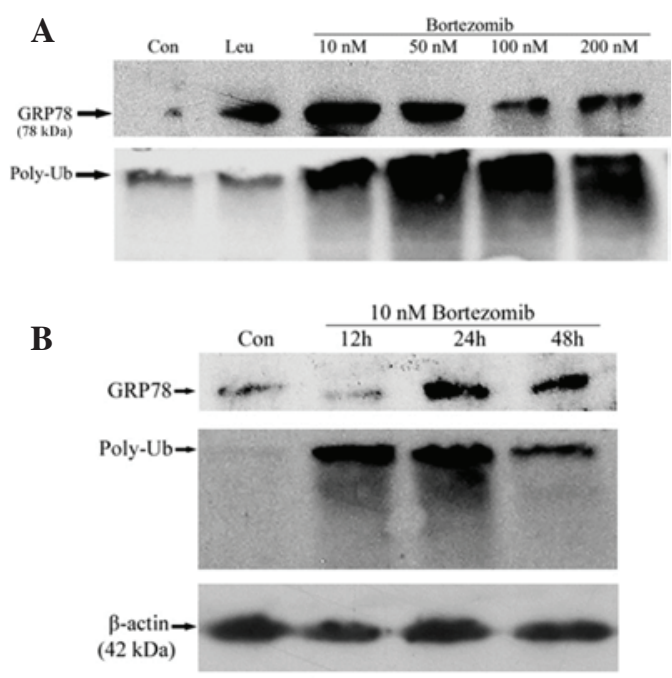

Figure 1. (A) Expression of GRP78 in response to various doses of bortezomib. Metastatic mouse breast cancer 4T1 cells were treated with bortezomib $(10,50$, 50,100 or $200 \mathrm{nM}$ ) and $10 \mu \mathrm{M}$ leupeptin for $24 \mathrm{~h}$. In total, $40 \mu \mathrm{g}$ protein were separated by $12 \%$ SDS-PAGE and probed with GRP78 (1:500) and ubiquitin (1:200) antibodies. Ubiquitin antibodies were used to determine the accumulation of poly-Ub. (B) Time-dependent analysis of GRP78 following treatment with $10 \mathrm{nM}$ bortezomib. The cells were treated with bortezomib for $0,12,24$ and $48 \mathrm{~h}$. In total, $25 \mu \mathrm{g}$ protein were separated by $12 \%$ SDS-PAGE and probed with GRP78 (1:500) or ubiquitin (1:200) antibodies. Equal protein loading was assessed with a $\beta$-actin antibody. GRP78, glucose-regulated protein $78 \mathrm{kDa}$; Con, control; Leu, leupeptin; poly-Ub, polyubiquitinated conjugates; SDS-PAGE, sodium dodecyl sulfate polyacrylamide gel electrophoresis.

of polyubiquitin conjugates were investigated by western blot analysis. As shown by Fig. 1A, polyubiquitin conjugates accumulated in a dose-dependent manner, which indicated that the proteasome was inhibited by bortezomib treatment.

To determine the time-dependent effects of bortezomib treatment, $4 \mathrm{~T} 1$ cells were treated with $10 \mathrm{nM}$ bortezomib for 12, 24 and $48 \mathrm{~h}$. Following $10 \mathrm{nM}$ bortezomib treatment, there was an increase in GRP78 expression at $24 \mathrm{~h}$, which was sustained until $48 \mathrm{~h}$ (Fig. 1B). By contrast, an accumulation of polyubiquitin conjugates was observed as early as $12 \mathrm{~h}$ following $10 \mathrm{nM}$ bortezomib-treatment (Fig. 1B), indicating that the increase in GRP78 expression occurs following inhibition of the proteasome. $\beta$-actin was used as a loading control.

Effects of the intracellular calcium chelator BAPTA-AM. In order to determine the combined effects of bortezomib and BAPTA-AM, the $\mathrm{IC}_{50}$ value of BAPTA-AM was investigated using a MTT assay. The $\mathrm{IC}_{50}$ value of BAPTA-AM was determined as $13.6 \mu \mathrm{M}$ in the breast cancer 4T1 cell line (Fig. 2). The $\mathrm{IC}_{50}$ value of bortezomib was previously determined as $71 \mathrm{nM}$ in $4 \mathrm{~T} 1$ cells (15). Since a previous study showed that the expression of antiapototic GRP78 protein may be suppressed in the presence of BAPTA-AM (12), the present study hypothesized that bortezomib + BAPTA-AM combination may be more cytotoxic. Subsequently, the combined effects of bortezomib and BAPTA-AM on the 4T1 cells was investigated based on the $\mathrm{IC}_{50}$ value of BAPTA-AM determined by the present study. The cells were treated with various doses of bortezomib ( $1 \mathrm{nM}$ and $10 \mathrm{nM})$ and BAPTA-AM (0.5 and $5 \mu \mathrm{M})$. As shown in Fig. 3A, the combination of $10 \mathrm{nM}$ bortezomib $+5 \mu \mathrm{M}$ BAPTA-AM was more effective compared

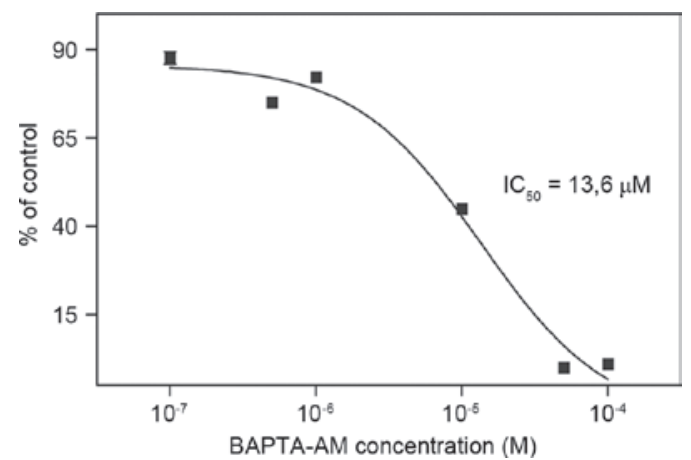

Figure 2. Determination of $\mathrm{IC}_{50}$ of BAPTA-AM in metastatic mouse breast cancer $4 \mathrm{~T} 1$ cells. Cells were treated with $100,500 \mathrm{nM}$ and 1, 10,50 and $100 \mu \mathrm{M}$ BAPTA-AM for $24 \mathrm{~h}$. The number of viable cells was determined by 3-(4,5-dimethylthylthiazol-2-yl)-2,5-diphenyl-tetrazolium bromide assay. $\mathrm{IC}_{50}$, half maximal inhibitory concentration.

A

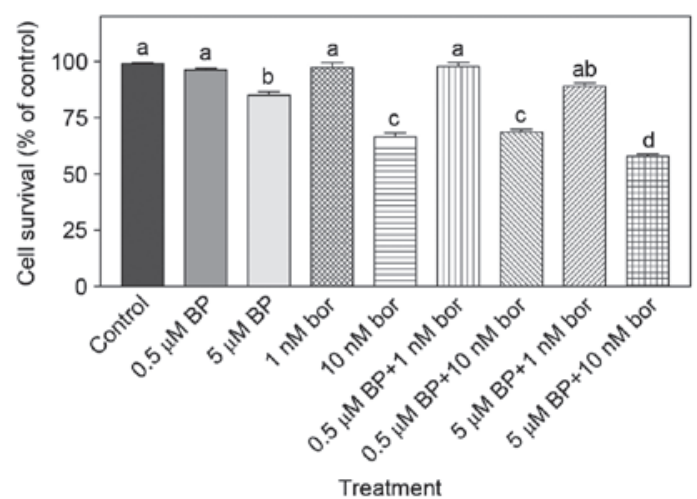

B

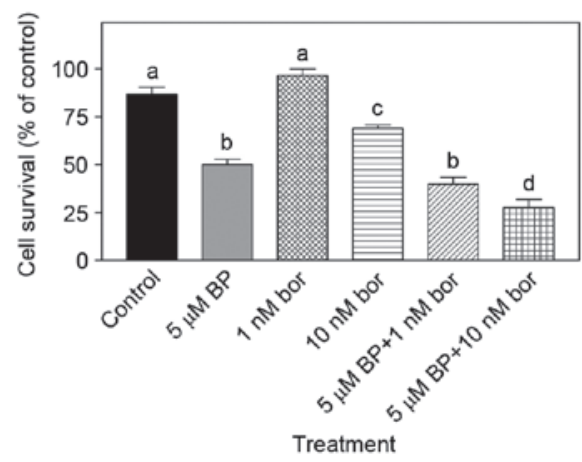

Figure 3. (A) Combined effect of bor and BP determined by MTT assay. Mouse breast cancer $4 \mathrm{~T} 1$ cells were treated with $0.5 \mu \mathrm{M} \mathrm{BP}, 5 \mu \mathrm{M} \mathrm{BP}, 1 \mathrm{nM}$ bor, $10 \mathrm{nM}$ bor alone or $0.5 \mu \mathrm{M} \mathrm{BP}+1 \mathrm{nM}$ bor $0.5 \mu \mathrm{M} \mathrm{BP}+10 \mathrm{nM}$ bor, $5 \mu \mathrm{M} \mathrm{BP}+1 \mathrm{nM}$ bor or $5 \mu \mathrm{M} \mathrm{BP}+10 \mathrm{nM}$ bor for $24 \mathrm{~h}$. The number of viable cells was determined by MTT assay (n=3). (B) Combined effect of bor and BP determined by WST-1 assay. Cells were treated with $5 \mu \mathrm{M}$ BP, $1 \mathrm{nM}$ bor or $10 \mathrm{nM}$ bor alone or $5 \mu \mathrm{M} \mathrm{BP}+1 \mathrm{nM}$ bor and $5 \mu \mathrm{M} \mathrm{BP}+10 \mathrm{nM}$ bor for $24 \mathrm{~h}$. The number of viable cells was determined by WST-1 assay $(n=8-9)$. Results are presented as the mean \pm standard error of the mean. Mean values that do not share a letter in common are significantly different $(\mathrm{P}<0.05)$. BP, BAPTA-AM; bor, bortezomib; MTT, 3-(4,5-dimethylthylthiazol-2-yl)-2,5-diphenyl-tetrazolium bromide.

with monotherapies (10 $\mathrm{nM}$ bortezomib or $5 \mu \mathrm{M}$ BAPTA-AM alone) $(\mathrm{P}<0.05)$. A WST-1 assay was used to verify the findings obtained by MTT assay and similar results were obtained; the combination of $10 \mathrm{nM}$ bortezomib $+5 \mu \mathrm{M}$ BAPTA was again significantly different compared with $10 \mathrm{nM}$ bortezomib or $5 \mu$ M BAPTA-AM treatment alone (P<0.001; Fig. 3B). 

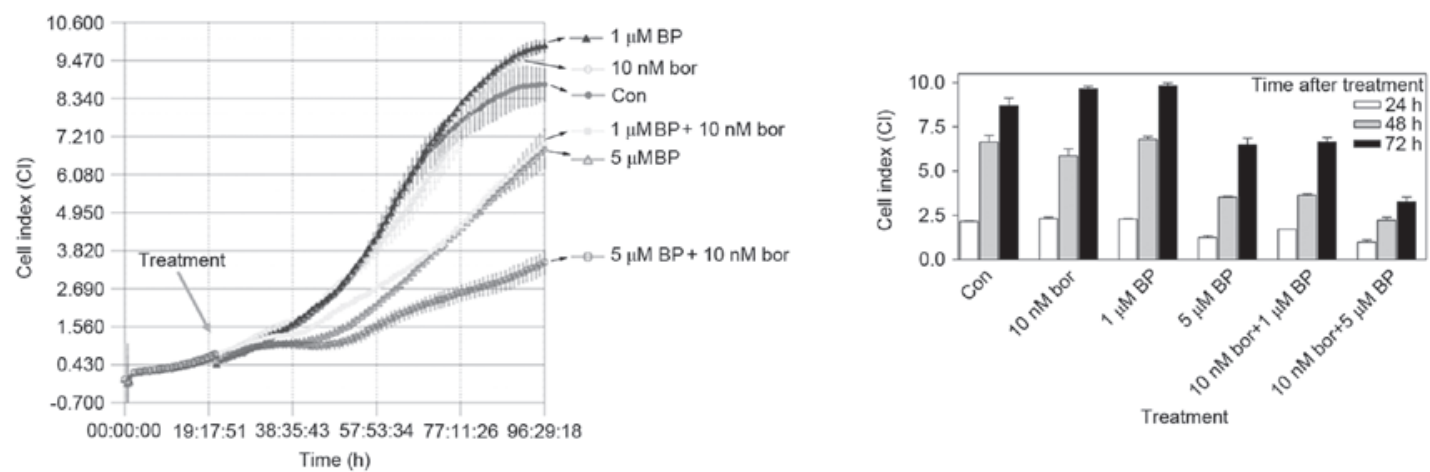

Figure 4. Combined effect of bor and BP determined by real-time iCELLigence system. After seeding, metastatic mouse breast cancer 4T1 cells were treated with $1 \mu \mathrm{M} \mathrm{BP}, 5 \mu \mathrm{M} \mathrm{BP}, 10 \mathrm{nM}$ bor alone or $1 \mu \mathrm{M} \mathrm{BP}+10 \mathrm{nM}$ bor and $5 \mu \mathrm{M} \mathrm{BP}+10 \mathrm{nM}$ bor at the logarithmic phase for $\sim 72 \mathrm{~h}$. The results are presented as the mean \pm standard deviation. BP, BAPTA-AM; bor, bortezomib; Con, control.

A

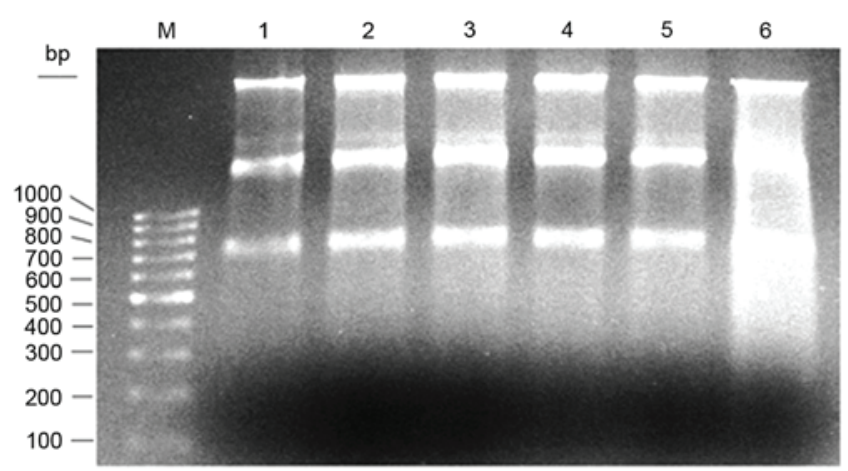

B


Figure 5. (A) Analyses of DNA fragmentation by Roche Apoptotic DNA-Ladder kit. Metastatic mouse breast cancer $4 \mathrm{~T} 1 \mathrm{cells}$ were treated for $24 \mathrm{~h}$ with $10 \mathrm{nM}$ bortezomib, $1 \mu \mathrm{M}$ BAPTA-AM, $5 \mu \mathrm{M}$ BAPTA-AM, $10 \mathrm{nM}$ bortezomib $+1 \mu \mathrm{M}$ BAPTA-AM and $10 \mathrm{nM}$ bortezomib $+5 \mu \mathrm{M}$ BAPTA-AM at the logarithmic phase of growth. Following treatment, DNA was isolated using the Roche Apoptotic DNA Ladder kit. For each DNA sample, equal amounts of DNA (1 $\mu \mathrm{g})$ was separated on a 1.5\% agarose gel. M, 100 bp marker; lane 1, control; lane 2, $10 \mathrm{nM}$ bortezomib; lane 3, $1 \mu \mathrm{M}$ BAPTA-AM; lane 4, $5 \mu$ M BAPTA-AM; lane $5,10 \mathrm{nM}$ bortezomib $+1 \mu \mathrm{M}$ BAPTA-AM; lane $6,10 \mathrm{nM}$ bortezomib $+5 \mu \mathrm{M}$ BAPTA-AM. (B) Determination of apoptotic effects of bortezomib and BAPTA-AM by MUSE ${ }^{\circledR}$ Cell Analyzer. $4 \mathrm{~T} 1$ cells were treated in the logarithmic phase of growth with $10 \mathrm{nM}$ bortezomib, $1 \mu \mathrm{M}$ BAPTA-AM, $5 \mu \mathrm{M}$ BAPTA-AM, $10 \mathrm{nM}$ bortezomib $+1 \mu \mathrm{M}$ BAPTA-AM or $10 \mathrm{nM}$ bortezomib $+5 \mu \mathrm{M}$ BAPTA-AM for $24 \mathrm{~h}$. Following treatment, the cells from each sample were stained using Annexin V and Dead Cell Reagent and analyzed by MUSE ${ }^{\circledast}$ Cell Analyzer. Results are representative of at least two experiments.

Effect of bortezomib + BAPTA-AM treatment on various cell processes. The combined effect of various concentrations of bortezomib + BAPTA-AM were investigated by the iCELLigence system, which is an impedance-based system for real-time monitoring of cellular processes, including cell growth, proliferation or cytotoxicity. In total, 12,500 cells, seeded onto E-Plates L8, were treated with $10 \mathrm{nM}$ bortezomib, $1 \mu \mathrm{M}$ BAPTA-AM, $5 \mu \mathrm{M}$ BAPTA-AM and the combinations of $10 \mathrm{nM}$ bortezomib $+1 \mu \mathrm{M}$ BAPTA-AM or $10 \mathrm{nM}$ bortezomib $+5 \mu \mathrm{M}$ BAPTA-AM in the logarithmic phase of 
growth. As shown by Fig. 4, although cells treated with $1 \mu \mathrm{M}$ BAPTA-AM and $10 \mathrm{nM}$ bortezomib were not different from the control, the combination of $10 \mathrm{nM}$ bortezomib $+1 \mu \mathrm{M}$ BAPTA-AM was significantly different compared with monotherapy following $24 \mathrm{~h}(\mathrm{P}<0.01), 48 \mathrm{~h}(\mathrm{P}<0.001)$ or $72 \mathrm{~h}(\mathrm{P}<0.01)$ of treatment. Similarly, $10 \mathrm{nM}$ bortezomib $+5 \mu \mathrm{M}$ BAPTA-AM reduced the growth of cells significantly compared with $10 \mathrm{nM}$ bortezomib treatment following $24 \mathrm{~h}(\mathrm{P}<0.001), 48 \mathrm{~h}(\mathrm{P}<0.001)$ or $72 \mathrm{~h}(\mathrm{P}<0.001)$ of treatment. The same combinations also produced significant results compared with $5 \mu \mathrm{M}$ BAPTA-AM alone following $24 \mathrm{~h}(\mathrm{P}<0.05), 48 \mathrm{~h}(\mathrm{P}<0.05)$ or $72 \mathrm{~h}(\mathrm{P}<0.001)$ treatment (Fig. 4).

Effects of bortezomib + BAPTA-AM on cell death. To determine whether cell death was mediated by necrosis or apoptosis in response to treatment with bortezomib + BAPTA-AM, DNA fragmentation was examined using a Roche Apoptotic DNA-ladder kit. As shown in Fig. 5A, DNA was not cleaved in response to a low dose of bortezomib $(10 \mathrm{nM}), 1 \mu \mathrm{M}$ BAPTA-AM, $5 \mu \mathrm{M}$ BAPTA-AM or $10 \mathrm{nM}$ bortezomib $+1 \mu \mathrm{M}$ BAPTA-AM after $24 \mathrm{~h}$; however, a clear increase in DNA fragmentation (as determined by smearing) was observed following treatment with $10 \mathrm{nM}$ bortezomib $+5 \mu \mathrm{M}$ BAPTA-AM for $24 \mathrm{~h}$ (Fig. 5A). To confirm that the combination of bortezomib + BAPTA-AM causes cell death primarily through apoptosis, the effect of each inhibitor alone or as combination in 4T1 cells was analyzed using Muse ${ }^{\circledR}$ Annexin V and Dead Cell Reagent. In control cells and cells treated with $10 \mathrm{nM}$ bortezomib, $1 \mu \mathrm{M}$ BAPTA-AM and $5 \mu \mathrm{M}$ BAPTA-AM, 6.3, $6.85,6.05$ and $9.65 \%$ early apoptotic cells were detected, respectively, following $24 \mathrm{~h}$ of treatment (Fig. 5B). By contrast, 10.8 and $15.35 \%$ of cells were early apoptotic following $24 \mathrm{~h}$ treatment with $10 \mathrm{nM}$ bortezomib $+1 \mu \mathrm{M}$ BAPTA-AM and $10 \mathrm{nM}$ bortezomib $+5 \mu \mathrm{M}$ BAPTA-AM combinations, respectively. This suggests that $10 \mathrm{nM}$ bortezomib $+5 \mu \mathrm{M}$ BAPTA-AM combination is more effective compared with inhibitor treatment alone or $10 \mathrm{nM}$ bortezomib $+1 \mu \mathrm{M}$ BAPTA-AM combination (Fig. 5B).

Determination of the bortezomib $+B A P T A-A M$ mechanism. To determine the growth-inhibitory and apoptotic mechanisms of bortezomib + BAPTA-AM combination, the activation/inactivation of various proteins and enzymes were analyzed by PathScan ${ }^{\circledR}$ Intracellular Signalling Array kit, which is a slide-based antibody array that uses sandwich immunoassay to detect phosphorylation or cleavage of 18 important signalling molecules. As shown by Fig. 6, although $10 \mathrm{nM}$ bortezomib, $1 \mu \mathrm{M}$ BAPTA-AM, $5 \mu \mathrm{M}$ BAPTA-AM and $10 \mathrm{nM}$ bortezomib $+1 \mu \mathrm{M}$ BAPTA-AM did not affect the phosphorylation level of SAPK/JNK, there was an $86 \%$ increase in SAPK/JNK phosphorylation with $10 \mathrm{nM}$ bortezomib $+5 \mu \mathrm{M}$ BAPTA-AM treatment, which suggests that the growth-inhibitory and apoptotic mechanisms may be mediated through the activation of SAPK/JNK. In addition, a significant increase in SAPK/JNK phosphorylation was detected in response to $100 \mathrm{nM}$ bortezomib alone, $100 \mathrm{nM}$ bortezomib $+1 \mu \mathrm{M}$ BAPTA-AM and $100 \mathrm{nM}$ bortezomib $+5 \mu \mathrm{M}$ BAPTA-AM (Fig. 6). There were 3.2, 3.7 and 3.9 fold increases observed following treatments with $100 \mathrm{nM}$ bortezomib, $100 \mathrm{nM}$ bortezomib $+1 \mu \mathrm{M}$ BAPTA-AM and

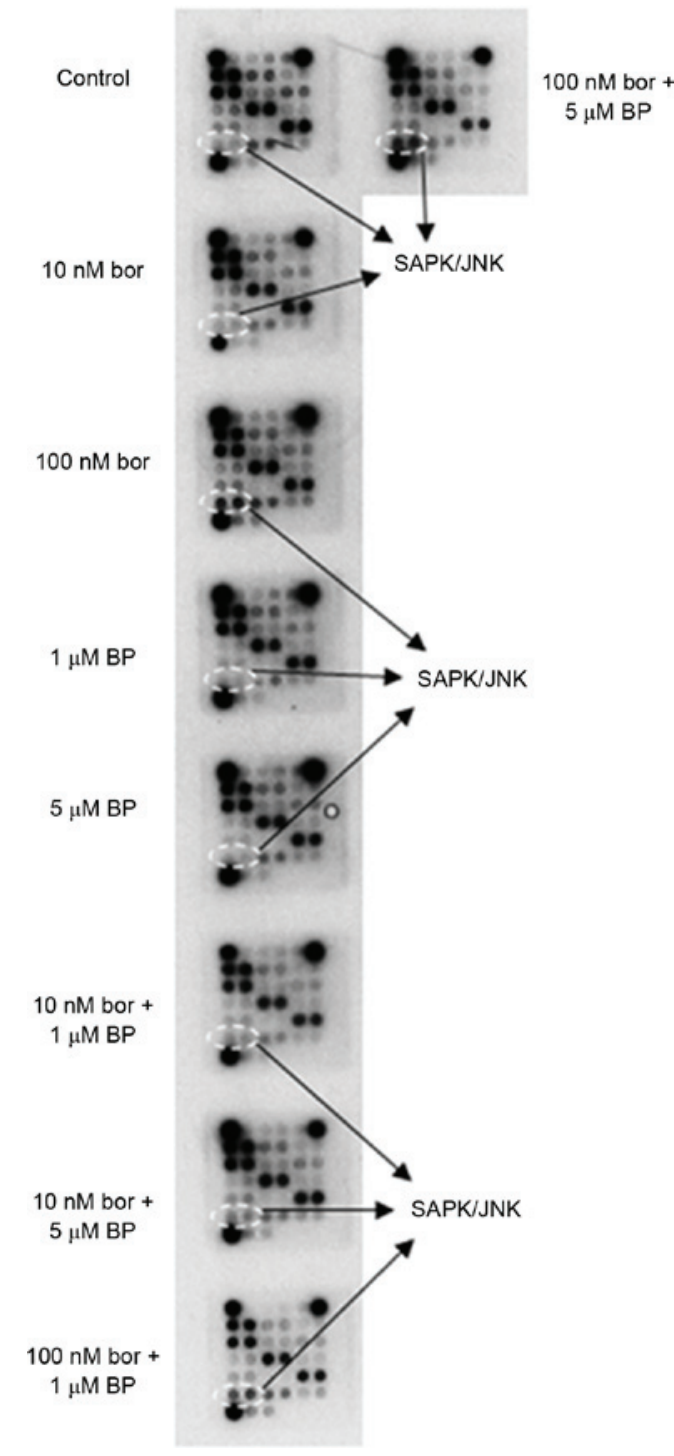

Figure 6. PathScan ${ }^{\circledR}$ Intracellular Array analysis. Metastatic mouse breast cancer 4T1 cells were treated with $10 \mathrm{nM}$ bor, $100 \mathrm{nM}$ bor, $1 \mu \mathrm{M}$ BAPTA-AM, $5 \mu \mathrm{M}$ BP alone or $10 \mathrm{nM}$ bor $+1 \mu \mathrm{M} \mathrm{BP}, 10 \mathrm{nM}$ bor $+5 \mu \mathrm{M} \mathrm{BP}, 100 \mathrm{nM}$ bor $+1 \mu \mathrm{M}$ BP or $100 \mathrm{nM}$ bor $+5 \mu \mathrm{M}$ BP at the logarithmic phase of growth for $24 \mathrm{~h}$. Following treatment, the cells were analyzed using the PathScan ${ }^{\circledR}$ Intracellular Signalling Array kit, according to the manufacturer's protocol. The slide was incubated with Lumi-GLO/peroxide reagent and exposed to Kodak BioMax X-ray films in dark room. The result is representative of two experiments, each run in duplicate. BP, BAPTA-AM; bor, bortezomib; SAPK/JNK, stress-activated protein and Jun amino-terminal kinases.

$100 \mathrm{nM}$ bortezomib $+5 \mu \mathrm{M}$ BAPTA-AM, treatment, respectively as compared to the DMSO-treated control. As shown in Fig. 6, analysis of the PathScan results indicated that there is no alterations in the phosphorylation or cleavage of the other 17 signalling molecules under the experimental conditions. This result may be partly due to the fact that the antibodies may not have recognized the mouse proteins, since $4 \mathrm{~T} 1$ breast cancer cells are derived from BALB/c mice.

\section{Discussion}

GRP78 overexpression has been observed in a number of malignant cells due to stress-inducing factors, including nutrient deprivation, hypoxia and acidosis in the microenvironment of 
poorly-perfused solid tumors (18). The induction of GRP78 favors cancer cell survival and also confers drug resistant phenotypes (6). Therefore, the present study investigated the expression of GRP78 following treatment with various doses of bortezomib in the metastatic mouse breast cancer $4 \mathrm{~T} 1$ cell line, which is a p53-null cell line (15) that is commonly used as an in vivo tumor formation model. The present results revealed that the expression level of GRP78 was increased significantly in a threshold- and time-dependent manner following low doses of bortezomib. In addition, the results suggest for the first time, to the best of our knowledge, that the $26 \mathrm{~S}$ proteasome and lysosomal organelle are involved in the regulation of GRP78 protein. Since GRP78 is an antiapoptotic protein that has been revealed to be responsible for chemotherapeutic resistance in a number of tumors and cell lines $(6,7)$, the present study rationalized that the therapeutic response to bortezomib may be increased by simultaneous inhibition of GRP78. Experiments performed in the present study revealed that a combination of a low dose of bortezomib $(10 \mathrm{nM})$ with $5 \mu \mathrm{M}$ BAPTA-AM, a strong inhibitor of GRP78 (19), caused significant cytotoxicity compared with monotherapy of bortezomib and BAPTA-AM, as determined by MTT assay. To verify these results, the cells were similarly treated with the same combination of drugs and cell viability was determined by WST-1 assay, which produced similar results as the MTT assay. An iCELLigence system, which allows real-time monitoring of cellular processes and offers distinct and important advantages over traditional end-point assays, revealed that $10 \mathrm{nM}$ bortezomib $+1 \mu \mathrm{M}$ BAPTA-AM and $10 \mathrm{nM}$ bortezomib $+5 \mu \mathrm{M}$ BAPTA-AM combination therapies reduced cell proliferation significantly compared with monotherapies for up to $76 \mathrm{~h}$ of treatment. These results not only demonstrate that combination therapy is more effective than monotherapy, but also indicate that the inhibitors are either stable for up to $72 \mathrm{~h}$ of incubation or damage the cells so that cell proliferation is clearly decreased at longer incubation times.

In addition, the present results revealed that $10 \mathrm{nM}$ bortezomib $+5 \mu \mathrm{M}$ BAPTA-AM combination treatment causes growth-inhibition and cell death through the induction of programmed cell death (apoptosis). To determine the mechanism of growth-inhibition and apoptosis, the phosphorylation or cleavage of 18 well-known signalling molecules was examined by PathScan analysis. This analysis revealed that there was a significant increase in the phosphorylation of SAPK/JNK following treatment with $100 \mathrm{nM}$ bortezomib alone or a combination of $10 \mathrm{nM}$ bortezomib $+5 \mu \mathrm{M}$ BAPTA-AM, $100 \mathrm{nM}$ bortezomib $+1 \mu \mathrm{M}$ BAPTA-AM or $100 \mathrm{nM}$ bortezomib $+5 \mu \mathrm{M}$ BAPTA-AM. SAPK/JNK belongs to the mitogen-activated protein kinase family, which is involved in the regulation of cell proliferation, differentiation and apoptosis (20). SAPK/JNK was originally identified as a stress-activated kinase linked to the cell death response, and is known to be activated by several stimuli, including growth factors, cytokines and stress factors (20). Proteasomal inhibition by MG132 was previously observed to potentiate leukemic cell apoptosis induced by flavopiridol through a SAPK/JNK- and NF- $\kappa \mathrm{B}$-dependent process (21). Similarly, exposure of chronic myeloid leukemia K562 and LAMA84 cells to bortezomib alone resulted in increased phosphorylation of SAPK/JNK (22). However, the findings presented by the current study revealed for the first time, to the best of our knowledge, that bortezomib alone or bortezomib + BAPTA-AM induced apoptosis in breast cancer 4T1 cells, which is associated with the phosphorylation/activation of SAPK/JNK.

A previous study revealed that there was an association between loss of sensitivity to the proteasome inhibitor and upregulation of the prosurvival chaperone GRP78 in mantle cell lymphoma samples and cell lines (23). In addition, Kern et al (24) indicated that bortezomib-resistant solid tumor PC-3 and HRT-18 cell lines were capable of secreting high amounts of GRP78. Kardosh et al (25) demonstrated that small interfering RNA-mediated knockdown of GRP78 renders tumor cells more sensitive to a combination of bortezomib and celecoxib treatment.

The present authors are currently investigating whether the expression of GRP78 is downregulated by BAPTA-AM in response to proteasome inhibitor bortezomib in 4T1 breast cancer cells. Overall, the results from the present study suggest that treatment protocols involving proteasome inhibitors in combination with BAPTA-AM may produce more effective and beneficial outcomes in the therapeutic responses of cancer patients harboring either a wild-type or mutant p53 gene. The present study also hypothesizes that the chemotherapy resistance in cancer cells may be prevented by simultaneous treatment of cancer cells with the proteasome inhibitor bortezomib and BAPTA-AM.

\section{Acknowledgements}

The present study was financially supported by the Scientific and Technological Research Council of Turkey (project no., 113S400).

\section{References}

1. Hendershot LM: The ER function $\mathrm{BiP}$ is a master regulator of ER function. Mt Sinai J Med 71: 289-297, 2004.

2. Hendershot LM, Valentine VA, Lee AS, Morris SW and Shapiro DN: Localization of the gene encoding human $\mathrm{BiP} / \mathrm{GRP} 78$, the endoplasmic reticulum cognate of the HSP70 family, to chromosome 9q34. Genomics 20: 281-284, 1994.

3. Murphy ME: The HSP70 family and cancer. Carcinogenesis 34: 1181-1188, 2013.

4. Roller C and Maddalo D: The molecular chaperone GRP78/BiP in the development of chemoresistance: Mechanism and possible treatment. Front Pharmacol 4: 10, 2013.

5. Qiu W, Kohen-Avramoglu R, Mhapsekar S, Tsai J, Austin RC and Adeli K: Glucosamine-induced endoplasmic reticulum stress promotes ApoB100 degradation: Evidence for Grp78-mediated targeting to proteasomal degradation. Arterioscler Thromb Vasc Biol 25: 571-577, 2005.

6. Zhang Y, Tseng CC, Tsai YL, Fu X, Schiff R and Lee AS: Cancer cells resistant to therapy promote cell surface relocalization of GRP78 which complexes with PI3K and enhances PI $(3,4,5) \mathrm{P} 3$ production. PLoS One 8: e80071, 2013.

7. Li B, Cheng XL, Yang YP and Li ZQ: GRP78 mediates radiation resistance of a stem cell-like subpopulation within the MCF-7 breast cancer cell line. Oncol Rep 30: 2119-2126, 2013.

8. Dong D, Ko B, Baumeister P, Swenson S, Costa F, Markland F, Stiles C, Patterson JB, Bates SE and Lee AS: Vascular targeting and antiangiogenesis agents induce drug resistance effector GRP78 within the tumor microenvironment. Cancer Res 65: 5785-5791, 2005.

9. Zhang J, Jiang Y, Jia Z, Li Q, Gong W, Wang L, Wei D, Yao J, Fang S and Xie K: Association of elevated GRP78 expression with increased lymph node metastasis and poor prognosis in patients with gastric cancer. Clin Exp Metastasis 23: 401-410, 2006. 
10. Wang HQ, Du ZX, Zhang HY and Gao DX: Different induction of GRP78 and CHOP as a predictor of sensitivity to proteasome inhibitors in thyroid cancer cells. Endocrinology 148: 3258-3270, 2007.

11. Mozos A, Roué G, López-Guillermo A, Jares P, Campo E, Colomer D and Martinez A: The expression of the endoplasmic reticulum stress sensor BiP/GRP78 predicts response to chemotherapy and determines the efficacy of proteasome inhibitors in diffuse large b-cell lymphoma. Am J Pathol 179: 2601-2610, 2011.

12. Chen LY, Chiang AS, Hung JJ, Hung HI and Lai YK: Thapsigargin-induced grp78 expression is mediated by the increase of cytosolic free calcium in 91 rat brain tumor cells. J Cell Biochem 78: 404-416, 2000.

13. Freshney RI: Culture of Animal Cells: A Manual of Basic Technique. Wiley-Liss, Hoboken, NJ, 2005.

14. Savran B, Yerlikaya A, Erdoğan E and Genç O: Anticancer agent ukrain and bortezomib combination is synergistic in 4T breast cancer cells. Anticancer Agents Med Chem 14: 466-472, 2014.

15. Yerlikaya A and Erin N: Differential sensitivity of breast cancer and melanoma cells to proteasome inhibitor velcade. Int $\mathrm{J}$ Mol Med 22: 817-823, 2008

16. Oerlemans R, Franke NE, Assaraf YG, Cloos J, van Zantwijk I, Berkers CR, Scheffer GL, Debipersad K, Vojtekova K, Lemos C, et al: Molecular basis of bortezomib resistance: Proteasome subunit beta5 (PSMB5) gene mutation and overexpression of PSMB5 protein. Blood 112: 2489-2499, 2008.

17. Chauhan D, Li G, Shringarpure R, Podar K, Ohtake Y, Hideshima T and Anderson KC: Blockade of Hsp27 overcomes bortezomib/proteasome inhibitor PS-341 resistance in lymphoma cells. Cancer Res 63: 6174-6177, 2003.
18. Ni M, Zhang Y and Lee AS: Beyond the endoplasmic reticulum: Atypical GRP78 in cell viability, signalling and therapeutic targeting. Biochem J 434: 181-188, 2011.

19. Wang Y, Wang W, Wang S, Wang J, Shao S and Wang Q Down-regulation of GRP78 is associated with the sensitivity of chemotherapy to VP-16 in small cell lung cancer NCI-H446 cells. BMC Cancer 8: 372, 2008

20. Dhanasekaran DN and Reddy EP: JNK signaling in apoptosis. Oncogene 27: 6245-6251, 2008.

21. Dai Y, Rahmani M and Grant S: Proteasome inhibitors potentiate leukemic cell apoptosis induced by the cyclin-dependent kinase inhibitor flavopiridol through a SAPK/JNK- and NF-kappaB-dependent process. Oncogene 22: 7108-7122, 2003.

22. Dai Y, Rahmani M, Pei XY, Dent P and Grant S: Bortezomib and flavopiridol interact synergistically to induce apoptosis in chronic myeloid leukemia cells resistant to imatinib mesylate through both Bcr/Abl-dependent and -independent mechanisms. Blood 104: 509-518, 2004.

23. Roué G, Pérez-Galan P, Mozos A, López-Guerra M, Xargay-Torrent S, Rosich L, Saborit-Villarroya I, Normant E, Campo E and Colomer D: The Hsp90 inhibitor IPI-504 overcomes bortezomib resistance in mantle cell lymphoma in vitro and in vivo by down-regulation of the prosurvival ER chaperone BiP/Grp78. Blood 117: 1270-1279, 2011.

24. Kern J, Untergasser G, Zenzmaier C, Sarg B, Gastl G, Gunsilius E and Steurer M: GRP-78 secreted by tumor cells blocks the antiangiogenic activity of bortezomib. Blood 114: 3960-3967, 2009.

25. Kardosh A, Golden EB, Pyrko P, Uddin J, Hofman FM, Chen TC, Louie SG, Petasis NA and Schönthal AH: Aggravated endoplasmic reticulum stress as a basis for enhanced glioblastoma cell killing by bortezomib in combination with celecoxib or its non-coxib analogue, 2,5-dimethyl-celecoxib. Cancer Res 68: 843-851, 2008. 